\title{
Negative-pressure pulmonary oedema following choking on a rice ball
}

\author{
Shinichi Miyazaki, Toshinori Matsui, Masahide Inoue, Takuya Ikeda
}

Department of Respiratory Medicine, Shiritsu Yokkaichi Byoin, Yokkaichi, Japan

Correspondence to Dr Shinichi Miyazaki, miyazaki.sin1@gmail.com

Accepted 11 November 2017

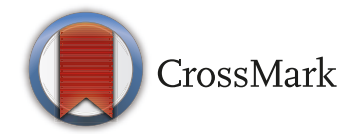

To cite: Miyazaki S, Matsui T, Inoue M, et al. BMJ Case Rep Published Online First: [please include Day Month Year]. doi:10.1136/bcr-2017222520

\section{DESCRIPTION}

A 74-year-old woman was brought to the emergency department by ambulance due to choking. Thirty minutes prior to presentation, the patient choked on a rice ball at lunch, and repeated banging on her back by family members led to successful dislodgement of a part of the object. The patient had a history of depression but no history of smoking.

On arrival, she was cyanotic and in respiratory distress. On physical examination, the patient was afebrile, with a heart rate of 112 beats per minute, blood pressure of $142 / 93 \mathrm{~mm} \mathrm{Hg}$, respiratory rate of 26 breaths per minute and oxygen saturation of $93 \%$ on $10 \mathrm{~L} / \mathrm{min}$ via face mask. Her body mass index was 27 (64 kg for $1.53 \mathrm{~m})$. Significant physical examination findings included inspiratory crackles in the right upper zone without wheezing, regular heart sounds without murmur or gallop, and no oedema.

A 12-lead ECG showed normal sinus rhythm with no ischaemic changes. Arterial blood gas analysis obtained on high-flow oxygen showed a $\mathrm{pH}$ of 7.17, a $\mathrm{PaCO}_{2}$ of $66 \mathrm{~mm} \mathrm{Hg}$, a $\mathrm{PaO}_{2}$ of $41 \mathrm{~mm} \mathrm{Hg}$ and $\mathrm{HCO}_{3}{ }^{-}$of $23 \mathrm{mmol} / \mathrm{L}$. Routine blood tests were unremarkable. A chest radiograph demonstrated consolidation, predominantly within the right upper lung, and to a lesser degree within the left upper lung (figure 1A). A CT scan of the chest revealed ground-glass opacities and consolidation bilaterally, as well as interlobular septal thickening with an upper lung predominance (figure 1B). The patient's clinical condition rapidly normalised over

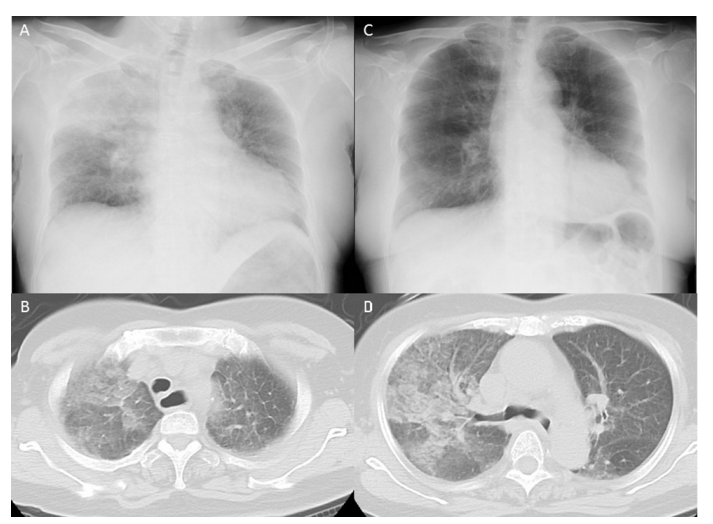

Figure 1 (A) Chest radiograph on admission, (B) CT scan of the chest on admission and (C) repeat chest radiograph at 24 hours after admission. the next few hours, and a repeat chest radiograph at 24 hours was normal (figure 1C).

Negative-pressure pulmonary oedema is a non-cardiogenic pulmonary oedema that can emerge shortly after relief of upper airway obstruction. ${ }^{1}$ Extremely large negative intrathoracic pressure against an obstructed airway leads to transudation of fluid across capillary membranes and formation of alveolar oedema. Pressure gradients between the thoracic cavity and interstitium tend to be more negative in central and non-dependent regions than in dependent and peripheral lung regions, ${ }^{2}$ which contribute to the central distribution of the pulmonary oedema. In an upright obese individual, the distribution of regional ventilation may be greatest in the upper lung zones and decreases towards the lower zones, whereas this distribution is reversed in non-obese individuals. ${ }^{3}$ This phenomenon may contribute to the pulmonary oedema predominant in the upper zones. Because resolution of the pulmonary oedema is usually rapid after relieving upper airway obstruction, treatment is supportive and includes close observation, supplemental oxygen and addition of positive-pressure ventilation.

\section{Learning points}

- Negative-pressure pulmonary oedema should be considered in differential diagnosis of non-cardiogenic pulmonary oedema after a choking incident.

- Body weight affects the distribution of regional ventilation, which may contribute to atypical radiological features in pulmonary oedema.

Contributors SM cared for the patient, performed the clinical reasoning and wrote the article. TM, MI and TI cared for the patient. Competing interests None declared.

Patient consent Obtained.

Provenance and peer review Not commissioned; externally peer reviewed.

(C) BMJ Publishing Group Ltd (unless otherwise stated in the text of the article) 2018. All rights reserved. No commercial use is permitted unless otherwise expressly granted.

\section{REFERENCES}

1 Bhattacharya M, Kallet RH, Ware LB, et al. Negative-pressure pulmonary edema. Chest 2016;150:927-33.

2 Bhaskar B, Fraser JF. Negative pressure pulmonary edema revisited: Pathophysiology and review of management. Saudi J Anaesth 2011;5:308-13.

3 Salome CM, King GG, Berend N. Physiology of obesity and effects on lung function. J Appl Physiol 2010;108:206-11. 
Copyright 2017 BMJ Publishing Group. All rights reserved. For permission to reuse any of this content visit http://group.bmj.com/group/rights-licensing/permissions.

BMJ Case Report Fellows may re-use this article for personal use and teaching without any further permission.

Become a Fellow of BMJ Case Reports today and you can:

- Submit as many cases as you like

- Enjoy fast sympathetic peer review and rapid publication of accepted articles

Access all the published articles

- Re-use any of the published material for personal use and teaching without further permission

For information on Institutional Fellowships contact consortiasales@bmjgroup.com

Visit casereports.bmj.com for more articles like this and to become a Fellow 